Jurnal Indonesia Sosial Teknologi: p-ISSN: 2723 - 6609

e-ISSN : 2745-5254

Vol. 2, No. 10 Oktober 2021

\title{
PERLINDUNGAN HUKUM TERHADAP PRAJURIT PEJUANG SEROJA YANG BERJUANG MULAI 18 JULI 1976 SAMPAI DENGAN 30 AGUSTUS 1999
}

\section{Syafaruddin}

Program Magister Ilmu Hukum Sekolah Tinggi Ilmu Hukum IBLAM, Jakarta, Indonesia

Email: syafaruddin.hadjar@gmail.com

\begin{abstract}
Abstrak
Operasi seroja yang di lakukan Pemerintah Indonesia dimulai pada tanggal 7 Desember 1975 ketika militer Indonesia masuk ke Timor Timur dengan alasan antikolonialisme. Pada Operasi Seroja yang tergabung dalam operasi tersebut tidak hanya dilakukan oleh Militer Indonesia saja tetapi masyarakat sipil Timor Timur turut serta membantu untuk menghancurkan Fretilin. Perjuangan yang luar biasa pada operasi seroja tersebut Pemerintah menganugerahkan tanda kehormatan atas jasa dan pengorbanan para pejuang yang telah membela dan mempertahankan kedaulatan negara kesatuan republik Indonesia berupa tanda kehormatan Veteran Republik Indonesia, dan masuk kategori Veteran Pembela Seroja sebagaimana diatur pada pasal 4 huruf c Undang-undang Nomor 15 Tahun 2012 tentang Veteran RI. Hal yang sangat disayangkan bagi pejuang operasi seroja yang turut serta pada operasi tersebut dengan kurun waktu 18 Juli 1976 sampai dengan 30 Agustus 1999 tidak mendapatkan anugerah tanda kehormatan Veteran RI sehingga hak-haknya sebagai seorang pejuang tidak dimiliki salah satunya adalah hak perlindungan hukum. Rumusan Masalah:1). Bagaimana Perlindungan Hukum terhadap Prajurit Seroja yang berjuang pada 18 Juli 1976 Sampai Dengan 30 Agustus 1999?. 2). Bagaimana Bentuk Perlindungan Hukum terhadap Prajurit Seroja yang berjuang pada 18 Juli 1976 Sampai Dengan 30 Agustus 1999?. Jenis penelitian yang penulis gunakan dalam menyusun tesis ini adalah penelitian hukum normatif dengan menggunakan data empiris yaitu penelitian yang mengkonsepsikan hukum sebagai norma meliputi nilai-nilai, dan juga sebagai hukum positif baik dalam peraturan perundang-undangan maupun hukum materiil yang berlaku di Indonesia. Penulis menyimpulkan bahwa perlindungan hukum yang dimaksud adalah menjamin kepastian hukum dan keadilan terhadap hak hak pejuang seroja yang berjuang pada tanggal 18 Juli 1976 sampai dengan 30 Agustus 1999 berupa hak mendapatkan pengakuan sebagai Veteran RI tentunya dengan merevisi Undang- undang Nomor 15 Tahun 2012 tentang Veteran RI.
\end{abstract}

Kata kunci: Perlindungan Hukum; Pejuang Seroja

\section{Abstract}

The seroja operation carried out by the Indonesian government began on 7 December 1975 when the Indonesian military entered East Timor on the grounds of anti-colonialism. In Operation Seroja, which was involved in the operation, it was 
not only carried out by the Indonesian military, but the East Timorese civil society also helped to destroy Fretilin. The extraordinary struggle in the Seroja operation, the Government awarded the honorary mark for the services and sacrifices of the fighters who had defended and defended the sovereignty of the unitary state of the Republic of Indonesia in the form of a Veterans of the Republic of Indonesia honor, and was included in the category of Veterans Defender of the Seroja as regulated in Article 4 letter $c$ of the Law. Law Number 15 of 2012 concerning Indonesian Veterans. It is very unfortunate for the combatants of the Seroja operation who participated in the operation from July 18, 1976 to August 30, 1999, did not receive the honorary award for the Indonesian Veterans, so that they did not have their rights as a fighter, one of which was the right to legal protection. Problem Formulation: 1). What is the legal protection for the Seroja Soldiers who fought from July 18, 1976 to August 30, 1999?. 2). What is the form of legal protection for the Seroja soldiers who fought from July 18, 1976 to August 30, 1999?. The type of research that the author uses in compiling this thesis is normative legal research using empirical data, namely research that conceptualizes law as a norm including values, and also as positive law both in statutory regulations and material law applicable in Indonesia. The author concludes that the legal protection in question is to guarantee legal certainty and justice for the rights of the Seroja fighters who fought on July 18, 1976 to August 30, 1999 in the form of the right to get recognition as a Veteran of the Republic of Indonesia, of course by revising Law Number 15 of 2012 concerning Veterans of the Republic of Indonesia.

Keywords: Legal protection; Holy Warriors

\section{Pendahuluan}

Kemerdekaan Republik Indonesia pada tanggal 17 Agustus 1945 yang dicapai saat itu merupakan hasil dari perjuangan rakyat Indonesia melalui serangkai perang dan pertumpahan darah untuk dapat meraihnya. Sebelum merdeka pun Indonesia harus mengalami penjajahan dari dua bangsa berbeda yaitu Belanda dan Jepang. Masa sulit itu yang membuat rakyat Indonesia bersatu untuk mengusir penjajah dan merebut kemerdekaan Indonesia (Basri, 2006). Pejuang kemerdekaan tersebar diseluruh pelosok nusantara, dari Sabang sampai Merauke ( Leirissa. R.z, 2004) (Leirissa. R.z, Sejarah Nasional Indonesia V, edisi revisi. Jakarta: PT. Sinar Utama, 2004, hlm 12) terkecuali wilayah Timor Timur yang saat itu belum menjadi bagian dari Indonesia sejak awal, berbeda dengan pulau Timor bagian barat yang dikuasai Belanda yang saat ini disebut sebagai Provinsi Nusa Tenggara Timur atau yang biasa disebut NTT.

Sebelum Operasi Seroja, pemerintah RI sudah melancarkan operasi intelijen dengan nama sandi Operasi Komodo pada 1974 untuk mencari info-info terkait politik di Timor Timur yang berpusat di Dili. Hasil penyelidikan ini terungkap bahwa Fretilin yang berpaham komunis dan menginginkan kemerdekaan lebih diminati oleh sebagian besar rakyat Timor Timur. Itulah yang menjadi alasan pemerintah RI dan AS melancarkan Operasi Seroja pada 7 Desember 1975. Terlebih, tanggal 28 November 1975, Fretilin menurunkan bendera Portugal dan mendeklarasikan Republik Demokratik Timor Leste. Kekuatan Fretilin ternyata tak sebanding dengan angkatan perang RI yang 
disebut-sebut mendapat bantuan dari Amerika Serikat. Malam hari tanggal 7 Desember 1975, Dili sudah bisa dikuasai. Tiga hari berselang, giliran kota terbesar kedua di Timor Timur, Baucau, yang direbut oleh militer Indonesia. Hanya setengah tahun sejak itu, tepatnya 17 Juli 1976, Timor Timur sepenuhnya dikuasai dan resmi menjadi bagian dari Negara Kesatuan Republik Indonesia sebagai provinsi ke-27. Kemudian pasca runtuhnya pemerintahan Orde Baru, diadakan referendum di Timor Timur pada 30 Agustus 1999. Hasilnya, wilayah ini lepas dari Indonesia dan berdiri sebagai negara sendiri bernama Timor Leste (https://tirto.id/sejarah-timor-timur-bergabung-dengannkri-peran-amerika-serikat-eesp, diakses pada tanggal 21 Juli 2021) .

Dari uraian tersebut bahwa operasi seroja yang di lakukan Pemerintah Indonesia dimulai pada tanggal 7 Desember 1975 ketika militer Indonesia masuk ke Timor Timur dengan alasan anti-kolonialisme. Penggulingan pemerintahan Fretilin yang tengah populer dan singkat memicu pendudukan selama seperempat abad dengan kekerasan di mana sekitar 100-180,000 tentara dan warga sipil diperkirakan tewas atau menderita kelaparan. Selama bulan-bulan pertama pendudukan, militer Indonesia menghadapi perlawanan pemberontakan yang berat di pedalaman pegunungan pulau, tetapi dari tahun 1977-1978, militer memperoleh persenjataan canggih baru dari Amerika Serikat, Australia, dan negara-negara lain, untuk menghancurkan basis Fretilin. Namun, dua dekade terakhir, melihat bentrokan terus-menerus antara kelompok Indonesia dan Timor Timur atas status Timor Timur, sampai tahun 1999, Timor Timur memilih untuk merdeka lewat referendum oleh misi PBB di Timor Timur.

Pada Operasi Seroja yang tergabung dalam operasi tersebut tidak hanya dilakukan oleh Militer Indonesia saja tetapi masyarakat sipil Timor Timur turut serta membantu untuk menghancurkan Fretilin, bila dilihat dari perjuangannya saat itu sungguh pengorbanan yang luar biasa untuk menjaga Timor Timur untuk menjadi bagian dari Negara Kesatuan Republik Indonesia, dimana pada saat perjuangan tersebut banyak korban, baik yang meninggal maupun yang cacat sampai saat ini namun perjuangan tersebut sia sia dengan Timor Timur merdeka melalui Referendum.

Perjuangan yang luar biasa pada operasi seroja tersebut Pemerintah menganugerahkan tanda kehormatan atas jasa dan pengorbanan para pejuang yang telah membela dan mempertahankan kedaulatan negara kesatuan republik Indonesia berupa tanda kehormatan Veteran Republik Indonesia, dan masuk kategori Veteran Pembela Seroja sebagaimana diatur pada pasal 4 huruf c Undang-undang Nomor 15 Tahun 2012 tentang Veteran RI. Tanda Kehormatan yang diberikan oleh Pemerintah terhadap pejuang pembela Seroja ternyata dibatasi hanya pada perjuangan Seroja dalam kurun waktu tanggal 21 Mei 1975 sampai dengan tanggal 17 Juli 1976 yang berperan secara aktif dalam operasi/pertempuran dalam kesatuan bersenjata Lihat pada Penjelasan Undang-undang Nomor 15 Tahun 2012 tentang Veteran RI pasal 4 huruf c.

Bila berbicara perjuangan pada operasi Seroja, fakta yang terjadi tidaklah cukup dengan kurun waktu tanggal 21 Mei 1975 sampai dengan tanggal 17 Juli 1976, karena perjuangan itu masih dilakukan sampai lepasnya Timor Timur menjadi Negara Timor Leste yaitu pada tanggal 30 Agustus 1999 (Wawancara dengan Kolonel Inf Rusman, 
Kasubdit Komunikasi Sosial Direktorat Veteran Ditjen Pothan Kemhan, dilaksanakan pada tanggal 3 Agustus 2021), hal yang sangat disayangkan bagi pejuang operasi seroja yang turut serta pada operasi tersebut dengan kurun waktu 18 Juli 1976 sampai dengan 30 Agustus 1999 tidak mendapatkan anugerah tanda kehormatan Veteran RI sehingga hak-haknya sebagai seorang pejuang tidak dimiliki salah satunya adalah hak perlindungan hukum.

Perlindungan Hukum bagi Veteran Republik Indonesia sebagaimana diatur dalam Peraturan Menteri Pertahanan Nomor 15 Tahun 2016 adalah kegiatan bantuan hukum yang dilaksanakan di pengadilan dan di luar pengadilan, bertindak selaku kuasa, mewakili, mendampingi, membela, atau melakukan tindakan hukum lainnya maupun pemberian nasihat hukum untuk Veteran Republik Indonesia Lihat pada pasal 1 angka 1 Peraturan Menteri Pertahanan Nomor 15 Tahun 2016 tentang Perlindungan Hukum bagi Veteran Republik Indonesia

Hal tersebut dipertegas kembali pada pasal 2 sampai dengan 4 Peraturan Menteri Pertahanan Nomor 15 Tahun 2016 tentang Perlindungan Hukum bagi Veteran Republik Indonesia. Oleh karena itu penulis teratrik untuk lebih dalam mengkaji bagaimana bentuk perlindungan hukum terhadap para prajurit pejuang Seroja yang berjuang mulai dari 18 Juli 1976 sampai dengan 30 Agustus 1999.

\section{Metode Penelitian}

\section{Jenis Penelitian}

Jenis penelitian yang digunakan penulis dalam penelitian ini adalah penelitian hukum normatif dengan menggunakan data empiris yaitu penelitian yang mengkonsepsikan hukum sebagai norma meliputi nilai-nilai, dan juga sebagai hukum positif baik dalam peraturan perundang-undangan maupun hukum materiil yang berlaku di Indonesia (Sugiyanto, 2012)

Metode pendekatan yang digunakan dalam hal ini menggunakan pendekatan secara yuridis normatif sebagaimana menurut Soerjono Soekanto dan Sri Mamudji menjelaskan bahwa (Soekanto \& Mamudji, 2014 hlm. 14-15)

"Pendekatan penelitian hukum normatif dilakukan dengan penelitian inventarisasi hukum positif, penelitian terhadap asas-asas hukum, sistematika hukum, taraf sinkronisasi vertikal dan horizontal dan sejarah hukum. Pendekatan yang menggunakan konsep legis positivis yang menyatakan bahwa hukum adalah identik dengan norma-norma tertulis yang dibuat dan diundangkan oleh lembaga-lembaga atau pejabat yang berwenang."

Berdasarkan pendapat di atas, maka metode pendekatan dalam penelitian ini mengacu pada norma-norma hukum yang terdapat dalam peraturan perundangundangan yang dalam hal ini berkaitan Perlindungan Hukum terhadap Prajurit Seroja yang berjuang pada 18 Juli 1976 Sampai Dengan 30 Agustus 1999.

\section{Tehnik Pengumpulan Data}


a. Penelitian lapangan (field research), yaitu penulis wawancara langsung dan terbuka dalam bentuk tanya-jawab atau pihak-pihak yang terkait yang berkaitan dengan permasalahan dalam tulisan ini.

b. Penelitian pustaka (library research), yaitu penulis juga mencari sumber-sumber data melalui studi kepustakaan, yaitu dengan mencari, menginventarisasi, mencatat, dan mempelajari data-data sekunder yang berhubungan dengan masalah yang dibahas.

\section{Analisis Data}

Data yang diperoleh melalui kegiatan penelitian kepustakaan maupun penelitian lapangan dianalisis secara kualitatif kemudian disajikan secara deskriptif, yaitu menguraikan, menjelaskan, dan menggambarkan sesuai penelitian ini guna menjawab dan memecahkan masalah serta pendalaman secara menyeluruh dan utuh dari objek yang diteliti guna menghasilkan kesimpulan yang bersifat deskripsi (Soekanto \& Mamudji, 2014)

\section{Hasil dan Pembahasan}

\section{A. Analisis Perlindungan Hukum Terhadap Prajurit Seroja Yang Berjuang Pada 18 Juli 1976 Sampai Dengan 30 Agustus 1999}

Pada dasarnya Gelar Veteran Pembela / Pejuang Seroja Republik Indonesia nampaknya bukanlah suatu kebanggan bagi ribuan pejuang negeri yang sekarang masih hidup. Veteran dengan rela mengorbankan air mata, darah bahkan nyawa mengusir penjajah dari Negara Republik Indonesia namun, kondisi yang sekarang terjadi belum semua Veteran dapat menikmati kerja kerasnya. Para Veteran justu merasa dirinya berada dalam keterasingan dan kemiskinan karena perubahan sistem pemerintah dan politik (Handayani, 2015).

Gugur dalam perang adalah suatu kehormatan bertahan hidup dalam menuntaskan peperangan melawan penjajah adalah suatu kebanggaan. Meski cacat dan kehilangan organ tubuh, tidak ada wajah pesimis dari pejuang seroja untuk menjalani hidup. Banyak dari pejuang seroja menggunakan kaki palsu, tangan palsu, mereka hidup layaknya masyarakat lainnya. Peraturan Menteri Pertahanan RI Nomor 15 Tahun 2016 tentang Perlindungan Hukum bagi Veteran RI yang diperoleh seperti pejuang veteran lainnya tak diperolehnya, padahal dalam kehidupan mereka di masa tuanya terkadang banyak persoalan-persoalan hukum, seperti perdata, pidana maupun bidang hukum lainnya.

Berdasarkan uraian tersebut, secara umum dikatakan ada beberapa hal yang menjadi alasan masyarakat membutuhkan mendapatkan perlindungan hukum yaitu (Philipus, 1987):

a. Karena dalam berbagai hal warga negara dan badan hukum perdata tergantung pada keputusan-keputusan pemerintah, seperti kebutuhan terhadap izin yang diperlukan untuk usaha perdagangan, perusahaan atau pertambangan. Karena itu warga negara dan badan hukum perdata membutuhkan perlindungan hukum. 
b. Hubungan antara pemerintah dan warga negara tidak berjalan dalam posisi sejajar, dan warga negara berada di pihak lemah dalam hal ini.

c. Berbagai perselisihan warga negara dengan pemerintah berkenan dengan keputusan, sebagai instrumen pemerintah yang bersifat sepihak dalam menentukan intervensi terhadap kehidupan warga negara.

Hukum dalam masyarakat bersifat melindungi artinya sifat hukum memberikan pengayoman, menyiratkan bahwa di dalam dirinya sudah mengandung sifatnya di dalam memberikan perlindungan yaitu yang dilindungi merasa aman dan sejahtera. Dalam pembukaan UUD 1945 terkandung asas mengayomi bangsa dan tanah air, salah satu butir yang menjadi acuan untuk menentukan pengertian hukum serta merupakan nilainilai dasar dari tata hukum kita adalah bersifat melindungi. Nilai dasar yang terkandung dalam perlindungan itu harus terwujud pula untuk segenap rakyat Indonesia sebagai ide keadilan sosial"(Dimyati, 2004).

Demikian pula dengan masyarakat khusus yaitu para pejuang seroja yang berjuang pada tanggal 18 Juli 1976 Sampai Dengan 30 Agustus 1999 yang membutuhkan perlindungan hukum kekhususan, hal tersebut dikarenakan para pejuang tersebut telah berperan menjalan tugas negara dan merupakan gerbang utama dalam meperjuangkan sebuah negara yang rela mengorbankan air mata, darah bahkan nyawa mengusir penjajah dari Negara Republik Indonesia namun, kondisi yang sekarang terjadi belum semua pejuang seroja dapat menikmati kerja kerasnya. Para pejuang seroja tersebut justru merasa dirinya berada dalam ketidakpastian karena perubahan sistem pemerintah dan politik.

Berkaitan dengan hal tersebut, perlindungan hukum yang dimaksud oleh pejuang seroja tersebut adalah:

a. Perlindungan hukum yang dimaksud adalah adanya upaya pemerintah untuk melindungi pejuang seroja yang berjuang pada tanggal 18 Juli 1976 Sampai Dengan 30 Agustus 1999, baik perlindungan harkat dan martabat maupun pengakuan terhadap hak hak sebagai pejuang seroja .

b. Perlindungan hukum yang merupakan kegiatan untuk melindungi pejuang seroja dengan menyerasikan hubungan nilai-nilai atau kaidah-kaidah yang menjelma dalam sikap dan tindakan dalam menciptakan adanya ketertiban dalam pergaulan hidup antar sesama manusia

c. Perlindungan Hukum yang memberikan pengayoman kepada hak hak asasi pejuang seroja tersebut yang dirugikan orang lain.

d. Perlindungan hukum yang dapat memberikan rasa aman baik secara pikiran maupun fisik dari gangguan dan berbagai ancaman dari pihak manapun

e. Perlindungan hukum yang merupakan segala upaya yang dapat menjamin kepastian hukum khususnya kepastian hukum terhadap masih adanya para pejuang seroja yang belum dirangkul oleh pemerintah sehingga belum ada jaminan bagi kelangsungan pejuang seroha tersebut dimasa kini dan mendatang.

f. Perlindungan hukum yang memberikan keadilan bagi para pejuang seroja tersebut terutama dalam hal kesejahteraan hidup. 
Dengan demikian dapat dikatakan bahwa suatu perlindungan dapat dikatakan sebagai perlindungan hukum apabila mengandung unsur-unsur sebagai berikut:

a. Adanya pengayoman dari pemerintah terhadap warganya, dalam hal ini pejuang seroja

b. Jaminan kepastian hukum

c. Berkaitan dengan hak-hak warga negara

d. Adanya sanksi hukuman (Rahardjo, 2003).

Prinsip-prinsip perlindungan hukum di Indonesia landasannya adalah Pancasila sebagai ideology dan falsafah negara yang didasarkan pada konsep Rechstaat dan Rule Of Law. Dimana prinsip perlindungan hukum Indonesia menitik beratkan pada prinsip perlindungan hukum pada harkat dan martabat manusia yang bersumber pada Pancasila. Sedangkan prinsip perlindungan hukum terhadap tindak pemerintah bertumpu dan bersumber dari konsep tentang pengakuan dan perlindungan terhadap hak-hak asasi manusia tersebut merupakan konsep yang lahir dari sejarah barat, yang diarahkan kepada pembatasanpembatasan dan peletakan kewajiban oleh masyarakat dan pemerintah (A Fadjar, 2005, hlm 13).

Tindakan hukum pemerintah merupakan tindakan-tindakan yang berdasarkan sifatnya menimbulkan akibat hukum. Karakteristik paling penting dari tindakan hukum yang dilakukan oleh pemerintah yaitu perbuatan yang besifat sepihak. Keputusan sebagai instrument hukum pemerintah dalam melakukan tindakan hukum sepihak, dapat menjadi penyebab terjadinya pelanggaran hukum terhadap warga negara, apalagi dalam negara hukum modern yang memberikan kewenangan yang luas kepada pemerintah untuk mencampuri kehidupan.

Oleh karena itu perlindungan hukum bagi warga negara khususnya pejuang seroja yang berjuang pada tanggal 18 Juli 1976 Sampai Dengan 30 Agustus 1999 adalah untuk mewujudkan tujuan-tujuan hukum, yakni keadilan, kemanfaatan dan kepastian hukum. Perlindungan hukum adalah suatu perlindungan yang diberikan kepada subyek hukum sesuai dengan aturan hukum, baik itu yang bersifat preventif (pencegahan) maupun dalam bentuk represif (pemaksaan), baik yang secara tertulis maupun tidak tertulis dalam rangka menegakkan peraturan hukum.

\section{B. Bentuk Perlindungan Hukum yang menjamin kepastian hukum}

Indonesia adalah negara hukum. Hal ini tercermin dalam Pasal 1 ayat (3) Undang-Undang Dasar Negara Republik Indonesia Tahun 1945 yang secara tegas menyatakan bahwa "Negara Indonesia adalah negara hukum". Sebagai Negara hukum maka seluruh aspek dalam bidang kemasyarakatan, kebangsaan, dan kenegaraan termasuk pemerintahan harus senantiasa berdasarkan atas hukum (https://www.kejaribone.go.id/artikel/detail/1/analisa-konsep-keadilan-kepastian-dan-kemanfaatan-dalampenegakan-hukum-tindak-pidana-pertambangan.html, diakses pada tanggal 5 September 2021). 
Secara historis, konsep negara hukum muncul dalam berbagai model, antara lain negara hukum menurut agama Islam, negara hukum menurut konsep Eropa Kontinental yang dinamakan rechsstaat, negara hukum menurut konsep Anglo Saxon (rule of law), konsep socialist legality, dan konsep negara hukum Pancasila.

Paham rechtstaats pada dasarnya bertumpu pada sistem hukum Eropa Kontinental, banyak dipengaruhi oleh sejarah perkembangan Eropa saat mulai sistem itu dikembangkan yaitu "absolutisme raja". (Wahjono, 1984)

\section{Hak mendapatkan pengamanan Hukum}

Pada dasarnya perlindungan hukum tidak membedakan terhadap kaum pria maupun wanita. Indonesia sebagai negara hukum berdasarkan pancasila haruslah memberikan perlindungan hukum terhadap warga masyarakatnya karena itu perlindungan hukum tersebut akan melahirkan pengakuan dan perlindungan hak asasi manusia dalam wujudnya sebagai makhluk individu dan makhluk sosial dalam wadah negara kesatuan yang menjunjung tinggi semangat kekeluargaan demi mencapai kesejahteraan bersama.

Perlindungan hukum terhadap para pejuang Seroja yang dimaksud adalah berkaitan dengan hak haknya yaitu hak mendapatkan pengakuan sebagai Veteran RI sebagaimana diaturan dalam Undang-Undang tentang Veteran RI, yang sampai saat ini belum didapatkan dikarena adanya pembatasan terhadap pejuang Seroja, sebagaimana disampaikan oleh Bapak Romidi yang megatakan Wawancara dengan Bapak Romidi, Veteran Seroja, dilaksanakan pada tanggal 7 September 2021:

Bahwa Saya termasuk yang cukup beruntung lantaran masa bakti sudah memenuhi ketentuan sehingga bisa memperoleh Perlindungan Hukum berupa hak hak asasi manusia seperti hak mendapatkan gelar kehormatan Veteran RI, mendapat santunan, bantuan kesehatan, sampai tunjangan cacat. Masalahnya tak semua seberuntung mereka. Perang Timor Timur terjadi dalam rentang waktu yang lama, sampai 1999. Artinya, ada banyak serdadu yang berhak mendapat status veteran namun terhalang poin penggolongan masa bakti tersebut.

"Ada banyak teman-teman saya yang bertugas setelah 1976, di lapangan terluka, tapi enggak dapat apa-apa. Mereka cacat, dan sayangnya enggak dapat status veteran. Kalau bisa pemerintah mengubah masa bakti itu."

Setiap tentara yang pernah turun berperang, baik melawan "musuh dalam maupun luar negeri," seharusnya berhak mendapat gelar veteran. "Karena pada dasarnya kami membela kesatuan negara, tidak peduli musuhnya siapa." Ini, kan, jadi enggak adil buat mereka"

Masalah Seroja tak sekali saja muncul. Di era lampau, menurut keterangan Romidi, juga terdapat masalah. Bedanya, titiknya terletak pada urusan pemberdayaan serdadu yang pulang dari medan perang dengan kondisi cacat permanen. Ketika ABRI dipimpin Maraden Panggabean (1973-1978), kebijakan 
yang diambil untuk merespons tentara Seroja yang pulang dengan kondisi demikian bertumpu pada tiga hal: pemulihan, pendidikan keterampilan, serta persiapan pensiun. Dengan kata lain, masa dinasnya diperpendek. "Itu seperti enggak peduli dengan nasib kami. Misalnya begini, kalau ada yang ikut operasi masih berusia muda, lalu kena tembak, bagaimana hidupnya setelahnya? Hancur pasti," jelas Romidi. Kebijakan Panggabean lalu dirombak oleh penerusnya, M. Jusuf (1978-1983), yang dikenal dekat dengan para tentara di bawahnya. Bagi tentara Seroja yang mengalami cacat permanen, pendekatan yang diambil yakni dipindahtugaskan menjadi staf di instansi terkait-bisa di ABRI maupun Departemen Pertahanan - sampai masa pensiunnya tiba. Dengan begitu, Romidi menambahkan, "ada jaminan yang bisa dipegang tentara." "Kasihan tentara kalau sudah pensiun jika negara tidak memperhatikan," tandasnya.

Perlindungan Hukum yang menjamin kepastian hukum terhadap hak-hak yang dimaksud sebagaimana diatur pada Peraturan Presiden Nomor 79 Tahun 2014 tentang Peraturan Pelaksanaan Undang-Undang Nomor 15 Tahun 2012 tentang Veteran RI, selain hak-hak Veteran RI yang disebutkan diatas ada hak-hak tertentu yang dapat diterima oleh Veteran RI, hak-hak tersebut diatur tersendiri oleh Peraturan Menteri dibidangnya masing-masing, hak-hak tersebut seperti Peraturan Presiden Nomor 79 Tahun 2014 tentang Peraturan Pelaksanaan Undang-Undang Nomor 15 Tahun 2012 tentang Veteran RI :

a. Keringanan bayar PBB sesuai dengan kebijakan daerah

b. Keringanan pembayaran biaya angkutan jasa transportasi milik negara

c. Keringanan biaya pendidikan untuk anak Veteran RI yang berusia di bawah 25 tahun

d. Jaminan kesehatan

e. Pemakaman di taman makam pahlawan bagi mereka yang mendapatkan bintang gerilya

f. Bimbingan usaha kecil dan menengah

g. Hak memperoleh perlindungan hukum.

Pada huruf g tercantum Hak memperoleh perlindungan hukum sebagaimana tercantum pada Peraturan Menteri Pertahanan No. 15 Tahun 2016 tentang Perlindungan Hukum Bagi Veteran Republik Indonesia, bahwa Perlindungan Hukum adalah kegiatan bantuan hukum yang dilaksanakan di pengadilan dan di luar pengadilan,bertindak selaku kuasa, mewakili, mendampingi,membela, atau melakukan tindakan hukum lainnya maupun pemberian nasihat hukum untuk Veteran Republik Indonesia 9 Pasal 1 angka 2 Peraturan Menteri Pertahanan No. 15 Tahun 2016 tentang Perlindungan Hukum Bagi Veteran Republik Indonesia.

Berdasarkan uraian tersebut bahwa prinsip perlindungan hukum bertumpu dan bersumber dari konsep tentang pengakuan dan perlindungan terhadap hak-hak asasi 
manusia karena menurut sejarah dari barat, lahirnya konsep-konsep tentang pengakuan dan perlindungan terhadap hak-hak asasi manusia diarahkan kepada pembatasanpembatasan dan peletakan kewajiban masyarakat dan pemerintah dalam hal ini VeteranRI, Selain itu perlindungan hukum terhadap tindak pemerintahan adalah prinsip negara hukum. Dikaitkan dengan pengakuan dan perlindungan terhadap hak-hak asasi manusia, pengakuan dan perlindungan terhadap hak-hak asasi manusia mendapat tempat utama dan dapat dikaitkan dengan tujuan dari negara hukum (A Fadjar, 2005).

\section{Hak memperoleh pemenuhan kesejahteraan hidup}

Kesejahteraan hidup merupakan bagian yang tidak terpisahkan dalam paradigma pembangunan ekonomi, pembangunan ekonomi dikatakan berhasil jika tingkat kesejahteraan hidup semakin baik, kesenjangan dan ketimpangan dalam kehidupan di akibatkan oleh keberhasilan pembangunan ekonomi yang tanpa disertai peningkatan kesejahteraan masyarakat.

Menurut Badrudin Kesejahteraan hidup yaitu suatu kondisi yang menunjukkan tentang keadaan kehidupan seseorang atau dapat dikatakan pula suatu keadaan terpenuhinya kebutuhan dasar yang terlihat dari rumah yang layak, tercukupinya kebutuhan akan sandang (pakaian) dan pangan (makanan), pendidikan,dan kesehatan, atau keadaan dimana seseorang mampu memaksimalkan utilitasnya pada tingkat batas anggaran tertentu dan kondisi dimana tercukupinya kebutuhan jasmani dan rohani (Badrudin, 2012).

Kesejahteraan hidup merupakan hak setiap individu sebagaimana diatur pada bagian Ketujuh Hak atas Kesejahteraan Pasal 36 yang menyatakan (Pasal 36 ayat (1), (2) dan (3) Undang-Undang No. 39 Tahun 1999 Tentang Hak Asasi Manusia) :

(1) Setiap orang berhak mempunyai milik, baik sendiri maupun bersama-sama dengan orang lain demi pengembangan dirinya, keluarga, bangsa, dan masyarakat dengan cara yang tidak melanggar hukum.

(2) Tidak seorangpun boleh dirampas miliknya dengan sewenang-wenang dan secara melawan hukum.

(3) Hak mempunyai fungsi sosial

(4) pengembangan dirinya, keluarga, bangsa, dan masyarakat dengan cara yang tidak melanggar hukum.

(5) Tidak seorangpun boleh dirampas miliknya dengan sewenang-wenang dan secara melawan hukum.

(6) Hak mempunyai fungsi sosial

Hak atas Kesejahteraan yang diterima Veteran RI sebagaimana diatur pada Undang-undang tentang Veteran sebagai berikut:

a. Tanda Kehormatan Veteran Republik Indonesia

Adalah penghargaan dan penghormatan negara yang diberikan oleh Presiden kepada warga negara Indonesia yang telah berjuang, membela, dan mempertahankan kedaulatan Negara Kesatuan Republik Indonesia dan/atau ikut melaksanakan perdamaian dunia. 
b. Dana Kehormatan Veteran Republik Indonesia yang selanjutnya disebut Dana Kehormatan

Adalah sejumlah uang yang diberikan setiap bulan yang merupakan penghargaan dan penghormatan dari negara.

c. Tunjangan Veteran Republik Indonesia

Adalah tunjangan yang merupakan penghargaan dan penghormatan negara.

d. Tunjangan bagi janda, duda, atau anak yatim veteran

e. Santunan cacat, tunjangan cacat, serta alat bantu yang dibutuhkan veteran

Tunjangan Cacat adalah tunjangan yang diberikan berupa uang setiap bulan dan selama hidupnya berdasarkan tingkat kecacatan dan golongan kecacatan.

Bahwa berdasarkan Hak memperoleh pemenuhan kesejahteraan hidup bagi pejuang seroja juga tidak mendapat pula Hak-hak kesejahteraan yang dimaksud, sehingga dapat dikatakan tidak mendapatkan hak yang sama karena adanya pembatasan dalam Undang Undang tentang Veteran RI, padahal bila penulis lihat dari sisi pejuang Operasi Seroja, kesuksesan operasi berhasil mencuatkan nama, pangkat, dan karier militer. Banyak prajurit yang berperan penting dalam operasi militer Seroja pada tanggal 18 Juli 1976 sampai dengan Agustus 1999 , Namun mereka nyaris tak dikenal dan tak dikenang karena mereka hanyalah prajurit biasa, Tapi keterlibatannya dalam upaya menyatukan Timor-timur masuk dalam Negara Kesatuan Republik Indonesia (NKRI) tak dapat dianggap tiada. Banyak pejuang Seroja juga meninggal sehingga membuat keluarga pelaku pedih menderita. Banyak keluarga yang ditinggal mati ayah, suami, kakak, adik, atau keluarga harus menanggung kecacatan mantan pejuang Seroja seumur hidup, seperti kaki atau tangan yang harus diamputasi serta ada juga yang kehilangan penglihatannya.

\section{Bentuk Perlindungan Hukum yang memberikan keadilan bagi pejuang seroja yang berjuang pada tanggal 18 Juli 1976 sampai dengan Agustus 1999}

Keadilan menurut Aristoteles, negara haruslah berdiri di atas hukum yang menjamin keadilan kepada warga negaranya. Keadilan merupakan syarat bagi tercapainya kebahagiaan hidup untuk warga negaranya, dan sebagai dasar dari pada keadilan itu perlu diajarkan rasa susila kepada setiap manusia agar ia menjadi warga negara yang baik. Dalam negara yang memerintah bukanlah manusia sebenarnya, melainkan pikiran yang adil, sedangkan penguasa sebenarnya hanya pemegang hukum dan keseimbangan saja (Kusnardi \& Ibrahim, 1998).

Dalam mengukur sebuah keadilan, menurut Fence M. Wantu mengatakan, "adil pada hakikatnya menempatkan sesuatu pada tempatnya dan memberikan kepada siapa saja apa yang menjadi haknya, yang didasarkan pada suatu asas bahwa semua orang sama kedudukannya di muka hukum (equality before the law). 
Atas dasar ini keadilan menolak jika lenyapnya kebebasan bagi sejumlah orang dapat dibenarkan oleh hal lebih besar yang didaptkan orang lain. Keadilan tidak membiarkan pengorbanan yang dipaksakan pada segelintir orang diperberat oleh sebagian besar keuntungan yang dinikmati banyak orang. Karena itu, didalam masyarakat yang adil kebebasan warga Negara dianggap mapan, hak-hak yang dijamin oleh keadilan tidak tunduk pada tawar menawar politik atau kalkulasi (John Rawls, A Theory Of Justice, Harvard University Press, Cambride, Massachusetts, 1995, hlm 3-4).

Adapun macam-macam keadilan adalah sebagai berikut (Santoso, 2012) :

1. Keadilan Legal atau keadilan Moral

Keadilan legal atau keadilan moral adalah menyangkut hubungan antara hubungan individu atau kelompok masyarakat dengan Negara. Intinya adalah semua orang atau kelompok masyarakat diperlakukan sama oleh Negara dihadapan hukum.

Dasar moralnya adalah:

a. Setiap orang adalah manusia yang mempunyai harkat dan martabat yang sama dan diperlakukan secara sama.

b. Setiap orang adalah warga Negara yang sama status dan kedudukannya, bahkan sama kewajiban sipilnya, sehingga harus diperlakukan sama sesuai dengan hukum yang berlaku.

Konsekuensi legal adalah:

a. Semua orang harus secara sama dilindungi hukum, dalam hal ini oleh negara.

b. Tidak ada orang yang diperlakukan secara istimewa oleh hukum atau Negara.

c. Negara tidak boleh mengeluarkan produk hukum untku kepentingan kelompok tertentu.

d. Semua warga harus tunduk dan taat kepada hukum yang berlaku.

2. Keadilan Distributif (keadilan ekonomi)

Keadilan distributif adalah distribusi ekonomi yang merata atau yang dianggap merata bagi semua warga negara. Menyangkut pembagian kekayaan ekonomi atau hasil-hasil pembangunan. Aristoles berpendapat bahwa distribusi ekonomi didasarkan pada prestasi dan peran masing-masing orang dalam mengejar tujuan bersama warga Negara. Keadilan akan terlaksana bilamana hal-hal yang sama diperlakukan secara sama dan hal-hal yang tidak sama secara tidak sama (justice is done when equals are treated equally).

3. Keadilan Komutatif

Keadilan komulatif ini bertujuan memelihara ketertiban masyarakat dan kesejahteraan umum. Mengatur hubungan yang adil atau fair antara orang yang satu dengan yang lain atau warga Negara satu dengan warga Negara 
yang lainnya. Menuntut agar dalam interaksi sosial antara warga satu dengan yang lainnya tidak boleh ada pihak yang dirugikan hak dan kepentingannya.

Hukum sangat erat hubungannya dengan keadilan, bahkan ada pendapat bahwa hukum harus digabungkan dengan keadilan, supaya benar-benar berarti sebagai hukum, karena memang tujuan hukum itu adalah tercapainya rasa keadilan pada masyarakat. Suatu tata hukum dan peradilan tidak bisa dibentuk begitu saja tanpa memerhatikan keadilan, karena adil itu termasuk pengertian hakiki suatu tata hukum dan peradilan, oleh karenanya haruslah berpedoman pada prinsip-prinsip umum tertentu. Prinsipprinsip tersebut adalah yang menyangkut kepentingan suatu bangsa dan negara, yaitu merupakan keyakinan yang hidup dalam masyarakat tentang suatu kehidupan yang adil, karena tujuan negara dan hukum adalah mencapai kebahagiaan yang paling besar bagi setiap orang (Santoso, 2012).

Berdasarkan uraian tersebut bentuk Perlindungan Hukum yang memberikan keadilan bagi pejuang seroja yang berjuang pada tanggal 18 Juli 1976 sampai dengan 30 Agustus 1999, mendapatkan tempat pada peraturan perundang-undangan tentang Veteran RI, berdasarkan hasil penelitian, penulis jelaskan sebagaimana tabel 1, sebagai berikut:

Tabel 1

Hasil Penelitian

\begin{tabular}{lll}
\hline No. & \multicolumn{1}{c}{ Nama } & \multicolumn{1}{c}{ Uraian } \\
\hline 1 Sukoro eks pejuang Timor Timur Tahun 1975- & Kami merasa \\
1978 (https://news.detik.com/berita/d- & dianaktirikan pemerintah, \\
346160/merasa-dianaktirikan-pejuang-seroja- & sebagai mantan pejuang \\
merebut Timor Timur & atau lebih dikenal Seroja, \\
dirikan-yayasan, diakses pada tanggal 8 & kami mendirikan \\
September 2021) & institusi khusus. Insitusi \\
& itu diberinama Yayasan \\
& Veteran RI khusus Seroja \\
& Timtim." \\
& Kalau menunggu \\
& kebijakan pemerintah, \\
& kami sudah tidak \\
& sanggup lagi \\
menunggunya
\end{tabular}




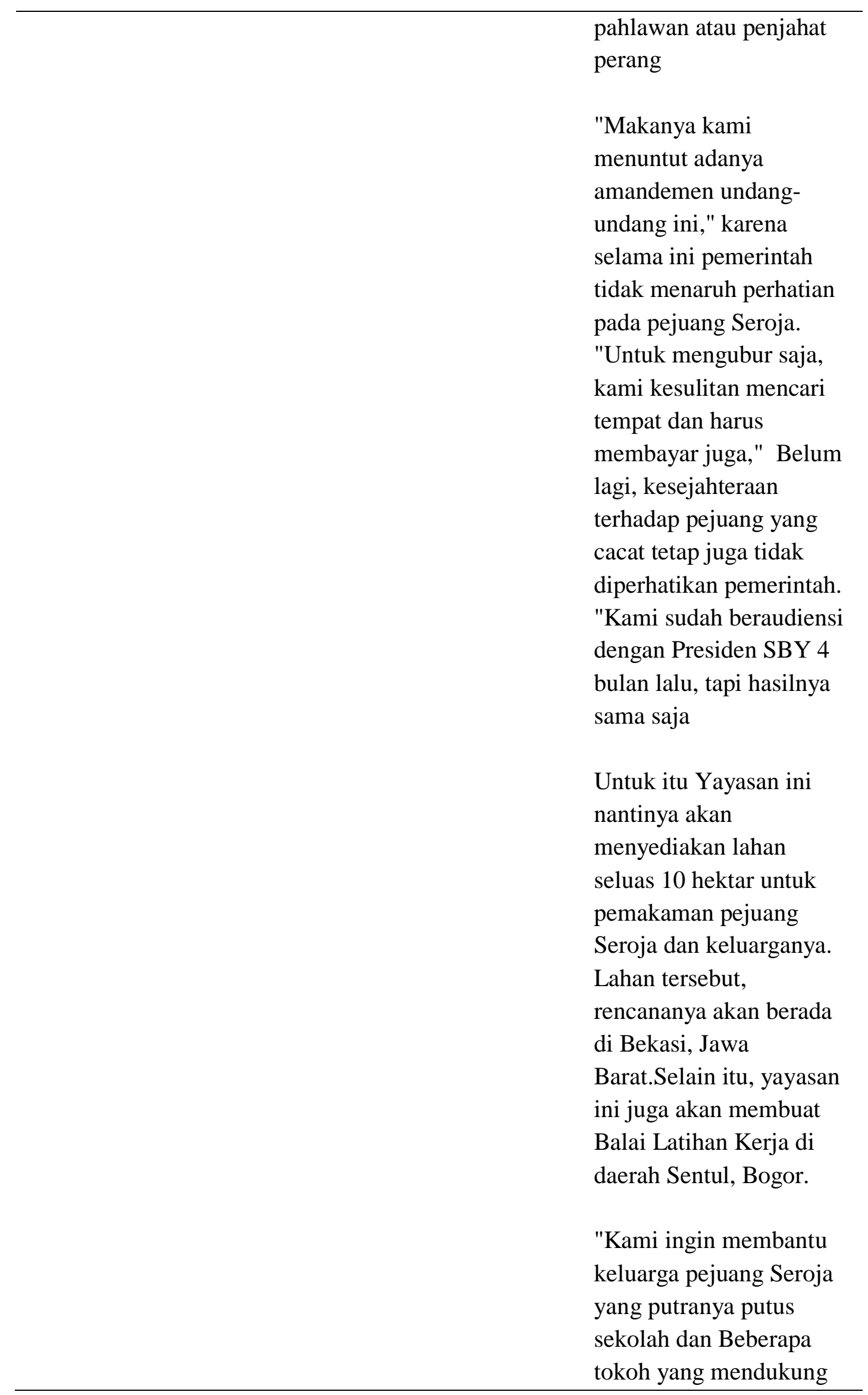




\begin{tabular}{|c|c|}
\hline & $\begin{array}{l}\text { yayasan ini antara lain } \\
\text { Mayjen (purn) } \\
\text { Suhardiman dan istri } \\
\text { Mayjen (purn) Amir } \\
\text { Mahmud. }\end{array}$ \\
\hline $\begin{array}{l}\text { Kolonel (Purn) H Syamsu Anwar, seorang } \\
\text { purnawirawan tentara Angkatan Darat yang } \\
\text { lama bertugas di Timor Timur } \\
\text { (https://jogja.tribunnews.com/2015/08/17/lipsus- } \\
\text { purnawirawan-eks-timtim-berharap-dapat-gelar- } \\
\underline{\text { veteran, diakses pada tanggal } 8 \text { September }}\end{array}$ & $\begin{array}{l}\text { Saya bertugas selama } 20 \\
\text { tahun di Timor Timur. Ia } \\
\text { berangkat pada 1977, } \\
\text { satu tahun setelah Timor } \\
\text { Timur terintegrasi pada } \\
17 \text { Juli 1976. Meski } \\
\text { bertugas di daerah yang } \\
\text { sudah terintegrasi dengan } \\
\text { Indonesia, tidaklah } \\
\text { ringan, terlebih } \\
\text { gesekan-gesekan dan } \\
\text { konflik terus terjadi. }\end{array}$ \\
\hline & $\begin{array}{l}\text { "Sebelum Juli } 1976 \text { dan } \\
\text { setelahnya sama saja } \\
\text { penderitaanya. Setelah } \\
1976 \text { malah lebih } \\
\text { menderita, karena terjadi } \\
\text { gesekan-gesekan, apalagi } \\
\text { menjelang tahun 1999, } \\
\text { luar biasa. }\end{array}$ \\
\hline & $\begin{array}{l}\text { Sejauh ini, UU Nomor } 15 \\
\text { tahun } 2012 \\
\text { tentang Veteran Republik } \\
\text { Indonesia justru } \\
\text { menghambatnya } \\
\text { memperoleh gelar } \\
\text { veteran. Disebutkan } \\
\text { dalam Undang-undang } \\
\text { tersebut, veteran Timor } \\
\text { Timur disebut } \\
\text { dengan Veteran Pembela } \\
\text { Seroja, yaitu Warga }\end{array}$ \\
\hline
\end{tabular}




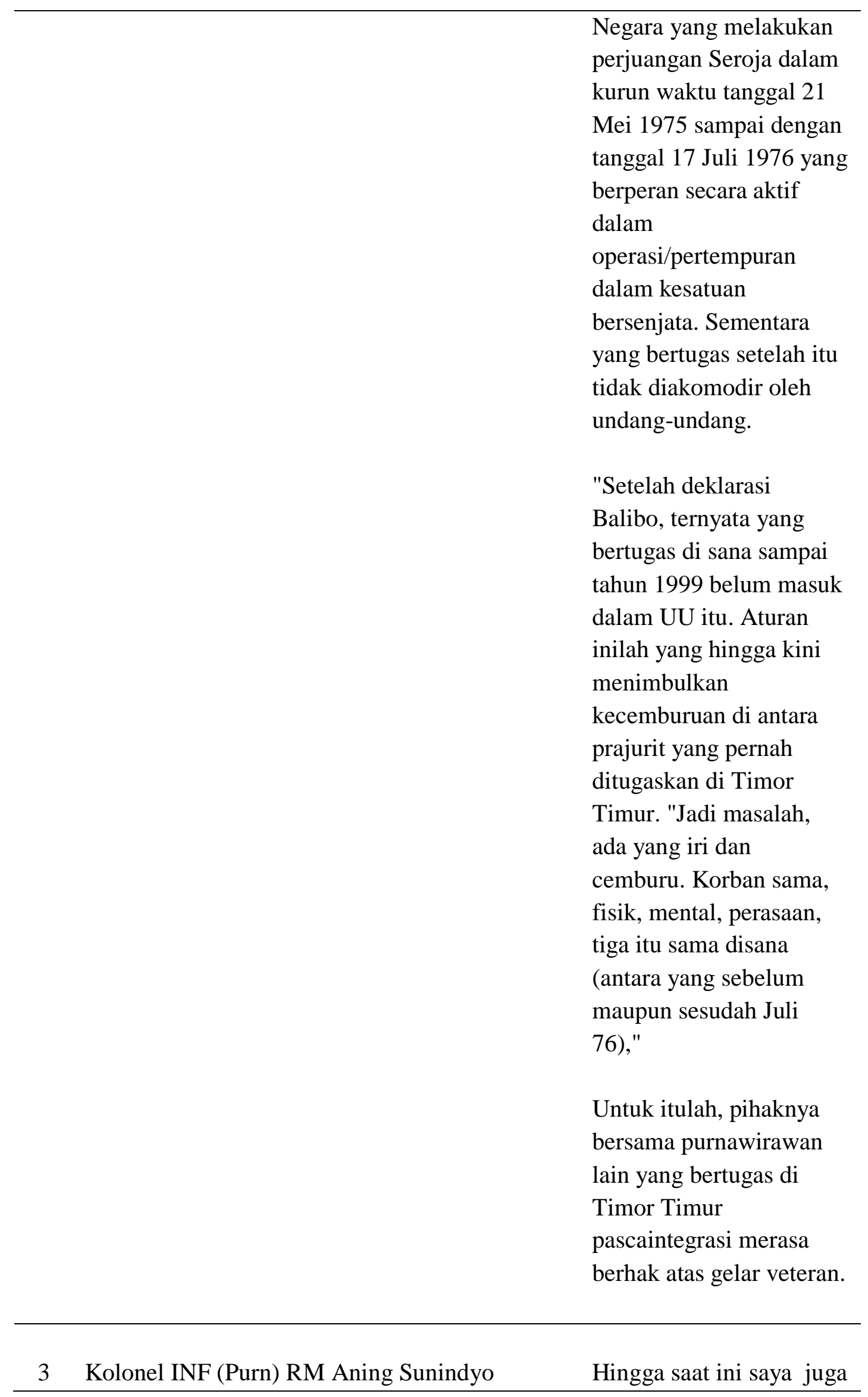




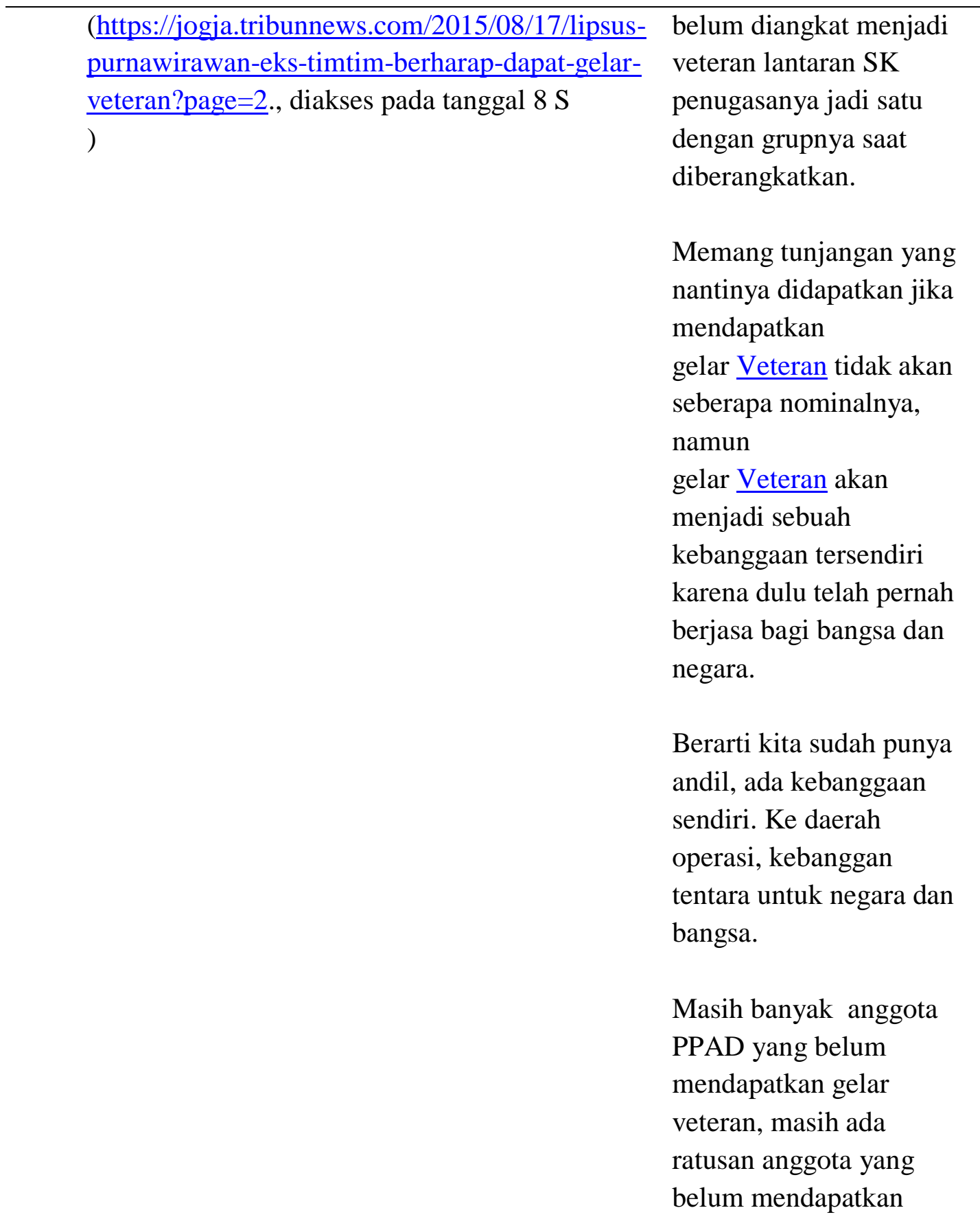

Sumber Data : diolah tahun 2021

Keterangan:

Berdasarkan uraian yang terdapat pada tabel 2, bahwasanya keinginan terbesar dari para pejuang seroja yang berjuang pada tanggal 18 Juli 1976 sampai dengan 30 Agustus 1999 adalah mendapatkan perhatian dari Pemerintah, sebagian besar mereka adalah anggota TNI dan Polri yang saat ini telah pensiun, mereka tidak memandang nilai tunjangan yang akan 
diterima tetapi lebih pada pengakuan bahwa mereka adalah bagian dari perjuang di Timor Timur, untuk itu keinginan terbesarnya adalah mendapatkan pengakuan sebagai Veteran Republik Indonesia sebagaimana diatur dalam Undang-Undang No. 15 Tahun 2012 tentang Veteran RI, namun yang sangat disayangkan adalah Undang-undang tersebut tidak merangkul mereka dengan ada pembatasan pada perjuangan di timor timur yaitu yang hanya berjuang pada tanggal 21 Mei 1975 sampai dengan tanggal 17 Juli 1976. Karenanya mereka merasa tidak mendapatkan keadilan atas hak haknya sebagai pejuang seroja.

Masalah keadilan merupakan persoalan yang rumit yang dapat dijumpai disetiap masyarakat. Hukum memiliki dua tugas utama yakni mencapai suatu kepastian hukum dan mencapai keadilan bagi semua masyarakat. Diantara sekian banyaknya pemikiran dan konsep keadilan, salah satu konsep keadilan yang cukup relevan adalah sebagaimana yang dikonsepsikan oleh Roscoe Pound, yang selanjutnya diketahui dengan keadilan sosiologis; keadilan yang didasarkan pada kebiasaan, budaya, pola perilaku dan hubungan antar manusia dalam masyarakat.

Keadilan hukum bagi masyarakat tidak sekedar keadilan yang bersifat formalprosedural, keadilan yang didasarkan pada aturan-aturan normatif yang rigid yang jauh dari moralitas dan nilai-nilai kemanusiaan. Lawan dari keadilan formal-prosedural adalah keadilan substantif, yakni keadilan yang ukurannya bukan kuantitatif sebagaimana yang muncul dalam keadilan formal, tetapi keadilan kualitatifyang didasarkan pada moralitas publik dan nilai-nilai kemanusiaan dan mampu mermberikan kepuasan dan kebahagiaan bagi masyarakat.

Hal yang normatif menurut penulis bahwa para pejuang tersebut berhak mendapatkan perlindungan Hukum yang memberikan keadilan bagi pejuang seroja yang berjuang pada tanggal 18 Juli 1976 sampai dengan Agustus 1999, karena pengorbanan mereka sungguh luar biasa yang tidak dapat di nilai dengan materi.

\section{Kesimpulan}

1. Kondisi yang sekarang terjadi belum semua pejuang seroja dapat menikmati kerja kerasnya. Para pejuang seroja tersebut justru merasa dirinya berada dalam ketidakpastian karena perubahan sistem pemerintah dan politik. Perlindungan Hukum terhadap Prajurit Seroja yang berjuang pada 18 Juli 1976 Sampai Dengan 30 Agustus 1999 belum diperoleh karena belum mendapatkan gelar kehormatan Veteran RI, sebagaimana diatur pada pasal 6 Undang-Undang No. 15 Tahun 2012 tentang Veteran RI, yang menyatakan " Tanda Kehomatan Veteran Republik Indonesia dapat diberikan kepada Warga Negara yang bergabung dalam kesatuan bersenjata resmi yang diakui oleh pemerintah yang berperan secara aktif dalam suatu peperangan menghadapi negara lain dan/atau gugur dalam pertempuran untuk membela dan mempertahankan kedaulatan Negara Kesatuan Republik Indonesia, atau Warga Negara yang berperan secara 
aktif dalam pasukan internasional di bawah mandat Perserikatan Bangsa-Bangsa untuk melaksanakan misi perdamaian dunia". Belum mendapatkannya gelar tersebut dikarenakan dalam Undang-Undang No.15 Tahun 2012 tentang Veteran RI terdapat pembatasan perjuangan sebagaimana diatur pada penjelasan Undang-Undang No.15 Tahun 2012 tentang Veteran RI pada pasal 4 huruf c. Sedangkan Perlindungan Hukum yang dimaksud oleh pejuang Seroja tersebut adalah

a. Perlindungan hukum yang dimaksud adalah adanya upaya pemerintah untuk melindungi pejuang seroja yang berjuang pada tanggal 18 Juli 1976 Sampai Dengan 30 Agustus 1999, baik perlindungan harkat dan martabat maupun pengakuan terhadap hak hak sebagai pejuang seroja .

b. Perlindungan hukum yang merupakan kegiatan untuk melindungi pejuang seroja dengan menyerasikan hubungan nilai-nilai atau kaidah-kaidah yang menjelma dalam sikap dan tindakan dalam menciptakan adanya ketertiban dalam pergaulan hidup antar sesama manusia

c. Perlindungan Hukum yang memberikan pengayoman kepada hak hak asasi pejuang seroja tersebut yang dirugikan orang lain.

d. Perlindungan hukum yang dapat memberikan rasa aman baik secara pikiran maupun fisik dari gangguan dan berbagai ancaman dari pihak manapun

e. Perlindungan hukum yang merupakan segala upaya yang dapat menjamin kepastian hukum khususnya kepastian hukum terhadap masih adanya para pejuang seroja yang belum dirangkul oleh pemerintah sehingga belum ada jaminan bagi kelangsungan pejuang seroha tersebut dimasa kini dan mendatang.

f. Perlindungan hukum yang memberikan keadilan bagi para pejuang seroja tersebut terutama dalam hal kesejahteraan hidup.

2. Bentuk Perlindungan Hukum terhadap Prajurit Seroja yang berjuang pada 18 Juli 1976 Sampai Dengan 30 Agustus 1999, diantaranya adalah:

a. Bentuk Perlindungan Hukum yang menjamin kepastian hukum

Segala daya upaya yang di lakukan secara sadar oleh setiap orang maupun lembaga pemerintah, swasta yang bertujuan mengusahakan pengamanan, penguasaan dan pemenuhan kesejahteraan hidup sesuai dengan hak-hak asasi yang ada sebagaimana di atur dalam Undang-undang Nomor 39 Tahun 1999 tentang Hak Asasi Manusia.

Hak-Hak asasi yang dimaksud oleh para pejuang Seroja yang berjuang pada tanggal 18 Juli 1976 sampai dengan Agustus 1999 adalah Hak mendapatkan pengamanan Hukum dan Hak memperoleh pemenuhan kesejahteraan hidup, yang penulis jelaskan sebagai berikut:

1) Hak mendapatkan pengamanan Hukum 
Perlindungan Hukum yang menjamin kepastian hukum terhadap hak-hak yang dimaksud sebagaimana diatur pada Peraturan Presiden Nomor 79 Tahun 2014 tentang Peraturan Pelaksanaan Undang-Undang Nomor 15 Tahun 2012 tentang Veteran RI, selain hak-hak Veteran RI yang disebutkan diatas ada hak-hak tertentu yang dapat diterima oleh Veteran RI, hak-hak tersebut diatur tersendiri oleh Peraturan Menteri dibidangnya masing-masing, hak-hak tersebut seperti:

a) Keringanan bayar PBB sesuai dengan kebijakan daerah

b) Keringanan pembayaran biaya angkutan jasa transportasi milik negara

c) Keringanan biaya pendidikan untuk anak Veteran RI yang berusia di bawah 25 tahun

d) Jaminan kesehatan

e) Pemakaman di taman makam pahlawan bagi mereka yang mendapatkan bintang gerilya

f) Bimbingan usaha kecil dan menengah

g) Hak memperoleh perlindungan hukum.

2) Hak memperoleh pemenuhan kesejahteraan hidup

Hak atas Kesejahteraan yang diterima Veteran RI sebagaimana diatur pada Undang-undang tentang Veteran sebagai berikut:

a) Tanda Kehormatan Veteran Republik Indonesia

b) Dana Kehormatan Veteran Republik Indonesia yang selanjutnya disebut Dana Kehormatan

c) Tunjangan Veteran Republik Indonesia

d) Tunjangan bagi janda, duda, atau anak yatim veteran

e) Santunan cacat, tunjangan cacat, serta alat bantu yang dibutuhkan veteran

f) Tunjangan Cacat adalah tunjangan yang diberikan berupa uang setiap bulan dan selama hidupnya berdasarkan tingkat kecacatan dan golongan kecacatan.

2. Bentuk Perlindungan Hukum yang memberikan keadilan bagi pejuang seroja yang berjuang pada tanggal 18 Juli 1976 sampai dengan Agustus 1999, diantaranya:

a. memberikan keadilan bagi pejuang seroja yang berjuang pada tanggal 18 Juli 1976 sampai dengan 30 Agustus 1999 dengan mendapatkan tempat pada peraturan perundang-undangan tentang Veteran RI.

b. Memberikan keadilan berupa perhatian secara hukum sebagai perlindungan hukum bagi pejuang seroja 
Syafaruddin

\section{Bibliografi}

A Fadjar, Mukti. (2005). Perlindungan Hukum. Bagus Media.

Badrudin, Rudy. (2012). Ekonomika otonomi daerah. UPP STIM YKPN.

Basri. (2006). Sejarah Perjuangan bangsa. Jakarta: Restu agung.

Dimyati, Khudzaifah. (2004). Teorisasi Hukum Studi Tentang Perkembangan Pemikiran Hukum di Indonesia, 1945-1990.

Handayani, Yeni. (2015). Pemenuhan Hak-Hak Veteran Republik Indonesia. Jurnal RechtsVinding Media Pembinaan Hukum Nasional, 2.

Kusnardi, Moh, \& Ibrahim, Harmaily. (1998). Pengantar Hukum Tata Negara Indonesia.

Philipus, M. Hadjon. (1987). Perlindungan Hukum Bagi Rakyat Indonesia. Bina Ilmu, Surabaya, 25.

R.z, Leirissa. (2004). Sejarah Nasional Indonesia V.

Rahardjo, Satjipto. (2003). Sisi-sisi lain dari Hukum di Indonesia. Penerbit Buku Kompas.

Santoso, Agus. (2012). Hukum, Moral, dan Keadilan. Sebuah Kajian Filsafat Hukum, Kencana Prenada Media Group, Jakarta.

Soekanto, Soerjono, \& Mamudji, Sri. (2014). Penelitian Hukum Normatif Suatu Tinjauan Singkat, cet. 16. Rajawali Pers, Jakarta.

Sugiyanto, D. (2012). Kedudukan Ilmu Hukum dalam Ilmu dan Filsafat. Bandung: $C V$. Mandar Maju.

Wahjono, Padmo. (1984). Guru Pinandito. Jakarta: Lembaga Penerbit Fakultas Ekonomi Universitas Indonesia. 